\title{
ФИДУЦИАРНЫЙ РЕЙТИНГ ФИЗИЧЕСКИХ ЛИЦ В УСЛОВИЯХ ЦИФРОВИЗАЦИИ ЭКОНОМИКИ РОССИИ: ВОЗМОЖНОСТИ И ОГРАНИЧЕНИЯ
}

\author{
(c) 2019 Коновалова Мария Евгеньевна \\ доктор экономических наук, зав. кафедрой экономической теории \\ Самарский государственный экономический университет, Россия, Самара \\ E-mail:mkonoval@mail.ru
}

(c) 2019 Суриков Константин Юрьевич

кандидат экономических наук

E-mail:sourikov.k@mail.ru

В статье рассматриваются вопросы реализации системы фидуциарного рейтинга физических лиц в условиях цифровизации экономики. Показаны возможные преимущества и ограничения, связанные с внедрением данного механизма. Доказано, что в условиях трансформации социальноэкономической системы, происходящей под воздействием цифровизации, хозяйственная деятельность индивидов становится все более транспарентной, что, с одной стороны, имеет явные преимущества, а с другой способствует возникновению негативных последствий. Достижение роста общественного благосостояния населения, обеспечение граждан необходимыми благами, социальными гарантиями возможно посредством применения технологии фидуциарного рейтинга.

Ключевые слова: доверие, фидуциирный рейтинг, цифровизация, социально-экономическая система, утилитаризм, демократия, денежная эмиссия.

В настоящее время происходит глобальная трансформация практически всех сторон человеческого бытия, что обусловлено интенсивным внедрением информационно-коммуникационных технологий во все стадии общественного воспроизводства. Изменения затрагивают не только объективные, реально протекающие хозяйственные процессы, но и субъективные представления индивидов о форме и характере имеющих место явлений. Активное внедрение искусственного интеллекта открывает перед обществом новые горизонты, позволяя достичь небывалых успехов не только в производственной деятельности, но и в решении социальных задач, направленных на рост благосостояния общества. Новая цифровая парадигма социальноэкономического развития базируется на применении такого фактора производства как знания [4]. В программе цифровизации, получившей развитие в Российской Федерации, обозначены базовые сегменты применения и использования когнитивных и облачных технологий, больших данных и интернета вещей.

Преимущества цифровой модели экономики основаны, прежде всего, на отсутствии материальности товаров (все большее их число становится виртуальным, появляется понятие электронно-сетевого блага), на виртуальности

экономических связей, значительном снижении потребности в ресурсах, на возможности быстрых перемещений в пространстве и времени, на использовании новых инвестиционных инструментов [11] и видов валют (речь идет о криптовалютах). Цифровая экономика базируется на трех составляющих: прежде всего, это рынки и отрасли, на которых происходит реальное взаимодействие между хозяйствующими субъектами, так же это платформы и технологии, обеспечивающие формирование компетенций для развития традиционных сфер хозяйства, и, наконец, среда, создающая условия для развития платформ и технологий, под которой понимается информационная инфраструктура, кадры и информационная безопасность [3].

Следует заметить, что внедрение цифровых технологий практически во все сферы жизнедеятельности человека существенным образом трансформирует саму систему координации экономических агентов, а также способы управления ими [2]. Использование в настоящее время практически всеми индивидами инструментов цифровизации [5], таких, например, как страховой номер индивидуального лицевого счета, пластиковая карта, электронный ключ, мобильные устройства, электронная почта делает доступным информацию о каждом из них, то есть 
происходит процесс «оцифровывания» каждого отдельно взятого гражданина, что повышает уровень транспарентности всей социальноэкономической системы. Огромные массивы данных о каждом из нас с одной стороны облегчают принятие различных решений, так как снижают размер трансакционных издержек, а с другой становятся объектов тотального контроля за жизнью населения. В обозримом будущем все общество может стать частью глобального цифрового паноптикума, в котором роль всевидящего ока отведена искусственному интеллекту, оценивающему поведение индивидуумов. Само понятие паноптикум было введено в оборот английским философом-моралистом и правоведом И. Бентамом, под которым он понимал модель существования индивидов, управляемых из единого центра, что делает их жизнь совершенно прозрачной. Первоначально такая форма координации применялась только в пенитенциарной системе (именно И. Бентам создал проект идеальной тюрьмы), однако в дальнейшем была признана достаточно эффективной и в управлении больницами, домами престарелых, промышленными предприятиями, школами и т.д.

Нельзя не отметить, что в своих размышлениях И. Бентам руководствовался моральными и этическими нормами, соблюдение которых, как он полагал, откроет дорогу к всеобщему счастью и процветанию [1]. Английский философ явился основоположником концепции утилитаризма (сочетание идей сенситивисткой психологии, этике гедонизма, классической политэкономии и демократической политики) поскольку связывал нравственное добро с удовольствием, наслаждением и максимальным удовлетворением своих потребностей. В своем трактате «Отрывок о правительстве» Бентам подчеркивает, что мерой правильности является наибольшее счастье наивозможно большего числа членов общества. Также он полагал, что при разработке законов следует опираться на два принципа: первый из них - это принцип наивысшего счастья, который должен служить нормативным ориентиром деятельности правительства, второй - психологического гедонизма, определяющего мотивы поведения людей, в частности их стремление удовлетворять или свои частные эгоистические интересы, или ориентироваться в своей деятельности на удовлетворение общественных потребностей. Сформированные государством законы, по мнению Бентама, способны или поощрять, или наказывать граждан за соответствующее поведение. Именно данному философу - моралисту принадлежит идея «исчисления счастья», то есть ранжирования удовольствия, наслаждения, а также страдания. По мнению Бентама, подобный расчет мог бы осуществляться при анализе любого законодательного акта или решения, затрагивающего интересы различных членов общества. При невозможности четкой оценки удовольствий и страданий, философ предлагает обращаться к их денежной форме. В дальнейшем положения И. Бентама нашли свое развитие в трудах Дж. Милля и Дж.С. Милля. Таким образом, еще в XVIII-XIX вв. зародились идеи создания общества, в котором все индивиды были бы проранжированы в соответствии с их поведенческими установками и формами достижения максимального удовлетворения.

В настоящее время сформулированные еще английскими философами и экономистами закономерности развития максимально транспарентного общества, жизнедеятельность которого базируется на гедонистических принципах, привели к росту научного и практического интереса к системе фидуциарного рейтинга физических лиц или системы социального кредита. Суть самой системы достаточно очевидна. Граждане, обладающие наивысшим рейтингом, который сигнализирует об их высоком уровне развития (значительном объеме накопленного человеческого капитала) [6], могут иметь существенные привилегии в пользовании основными жизненными благами (иметь высшую форму наслаждения, если говорить языком Бентама), индивиды, не достигшие же определенной позиции в рейтинге, не получат доступа к необходимым товарам, услугам, местам трудоустройства и т.д.

Рассмотрим возможности и ограничения применения системы фидуциарного рейтинга [7]. Прежде всего, хотелось бы отметить, что практический опыт внедрения такого механизма уже существует в качестве пилотного проекта в отдельных регионах КНР с 2014 года, с планами повсеместного его распространения к 2020 году. Каждому гражданину присваивается определенное количество баллов от 15000 (индекс А) до 500 (D), и ниже, формируя таким образом рейтинг от самых благонадежных, добросовестных индивидов до маргинальных личностей. С одной стороны, понятны выгоды такой всеобщей «оцифровки» для законопослушных граждан, ведь они могут пользоваться значительным 
объемом жизненных благ на достаточно льготных условиях, например, брать в банке кредит по сниженной ставке и без залога, покупать билеты на транспорт по выгодному тарифу, занимать руководящие должности и т.п. С другой стороны, жизнь граждан, не пользующихся доверием со стороны государства становится достаточно трудной, с большим количеством ограничений (в трудах И. Бентама такие последствия связаны с санкциями за несоблюдение законов). Например, для подобного рода граждан станут не доступны кредиты, прокат товаров, покупка билетов на транспорт, рабочие места в государственных учреждениях и т.д. Так, в 2018 году 15 млн. китайцев уже не смогли купить билеты на поезд, воспользоваться кредитом, устроиться на работу, поскольку они получили низкие баллы и не соответствовали необходимым критериям. Как повысить свой рейтинг известно чисто теоретически, понятно, что необходимо соблюдать законы, платить вовремя налоги, отвечать по кредитным обязательствам и т.д. Но в реальной практике не так все однозначно. Проблема в том, что поведение индивидов оценивает искусственный интеллект, который лишен имманентно присущих человеку чувств, эмоций, придающих его поступкам непредсказуемость и иррациональность. Так, например, один и тот же факт покупки субъектом успокоительного в аптеке может по-разному трактоваться, и скорее всего, всевидящим оком искусственного интеллекта он будет истолкован как наличие серьезных психологических проблем у индивида, а, следовательно, его ограниченной благонадежности для государства. Еще одним негативным последствием ранжирования граждан является воспроизводство таких негативных явлений как доносительство, всеобщая подозрительность, потеря персонифицированного доверия. Граждане вынуждены будут следить друг за другом в целях повышения индивидуального рейтинга. Таким образом система, задуманная, как раз для роста институционального доверия, будет подрывать его изнутри, создавая очаги межвидового напряжения, порождая все большую дискриминацию отдельных граждан. Реализация данного механизма приводит и к обострению трастовой конкуренции (борьбе за доверие) между государством и прочими социальными институтами. В Китае, технологии выставления рейтинга доверия частным лицам являются прерогативой государственной власти, что неизбежно ведет к потере значимости других социальных институтов, таких как частные психологи, религиозные и общественные организации. Еще в прошлом веке человек, потерявший доверие со стороны государства, все еще мог быть реабилитирован другими социальными институтами, например, церковью. Сейчас же в эпоху тотальной информатизации и глобального контроля это невозможно. Реализуемая в Китае модель социального кредита может иметь долгосрочные негативные последствия, которые, государство пока не считает серьезными, поскольку в текущий момент преимущества от роста транспарентности системы перевешивают потенциальные угрозы. Напротив, власти КНР всячески популяризирует данный механизм, превращая при этом жизнь своих граждан в паноптикум. Более того речь идет не просто о рекламе участия граждан в данной системе, а по сути обязательном включении хозяйственных акторов в социальный рейтинг, что, естественно, существенно ограничивает свободу индивидов в принятии ими решений и реализации своих потребностей.

В России официальными властями заявлено, что система социального кредита применяться не будет. Тем не менее рост «оцифровывания» человека продолжается, крупнейшим банком ПАО «Сбербанк» уже осуществляется сбор биометрических данных индивидов, по сути, на одном цифровом носителе будет храниться значительный объем данных на каждого субъекта, что сделает его практически прозрачным для государственных институтов. Следует отметить, что отдельные элементы фидуциарного рейтинга применяются уже давно, прежде всего, это процедура кредитного скоринга. В настоящее время она усовершенствована, за счет внедрения практики выставления баллов в кредитной истории клиента.

Как нам видится, происходящие процессы необратимы и отражают объективную реальность, связанную с внедрением во все сферы жизнедеятельности информационных технологий. Сломать эту систему уже невозможно, как и абстрагироваться от нее, остается только приспособиться и попытаться извлечь максимальную пользу как для отдельного индивида, так и общества в целом. Принимая во внимание опыт Китая, где система социального кредита используется в основном в целях усиления контроля за гражданами, необходимо использовать отдельные инструменты фидуциарного рейтинга толь- 
ко в направлении поощрения законопослушных граждан, не ограничивая при этом доступ к благам других членов общества, не обладающих безупречной репутацией. Еще одной задачей, решение которой возможно в условиях реализации механизма фидуциарного рейтинга, может стать повышение уровня как деперсонифицированного, так и персонифицированного доверия, что будет способствовать замене вертикального типа координации хозяйствующих субъектов на горизонтальный. Действительно, в условиях транспарентности социально-экономической системы, на наш взгляд, приоритетная роль должна быть у регулирующей функции государственных институтов, нежели контролирующей, как это происходит в текущей момент времени. Таким образом принципиальным отличием механизма социального кредита реализуемого в КНР от предлагаемого нами, является только добровольное участие граждан в данной рейтинге. Речь не идет об использовании данной системы в целях усиления государственного контроля и ограничения свободы граждан в осуществлении текущих операций.

Выше мы отмечали, что глобальные процессы цифровизации затрагивают практически все сферы социально-экономической системы, не остается в стороне и денежное обращение, в котором, как нам видится в настоящее время происходят существенные изменения. Постепенно набирающая обороты децентрализация системы денежного обращения, за счет, например, появления и активного распространения криптовалют, делают отдельно взятого субъекта все более автономным и независимым от ключевых финансовых институтов [9]. Человек становится более самодостаточным, самостоятельным, его решения, поведение делаются более значимыми в определении движения денег. По сути, опираясь на данные фидуциарного рейтинга, Центральный Банк может осуществлять денежную эмиссию детерминируя потребностями отдельного гражданина и принимая во внимания накопленные им размеры как материального, так и человеческого капитала. Уровень технического оснащения и глобализации движения денег в настоящее время настолько высок, что практически каждый субъект может быть включен в процесс эмиссии денег. Одновременно, техника способна взять на себя все функции по сбору и анализу информации, принятию решения о выдаче кредитов, переводу денег получателю (например, на пластиковую кредитную карту) и списанию платежей в погашение долга (с зарплатных карт). Уже сейчас Сбербанк запустил проект «Кредитная фабрика», покрывающий всю территорию страны, в котором 34 тыс. кредитных специалистов вводят в систему данные, проверяемые во внутренних и внешних структуpax (бюро кредитных историй, ФМС и т.д.). Это позволяет в 64\% случаев принимать решение о выдаче или отказе в кредите в автоматическом режиме, без привлечения человека. Сроки принятия решения сокращаются с двух недель до 17 часов, причем 10\% кредитных заявок обрабатывается в течение часа. Подобно тому, как в настоящий момент времени центральные банки, опираясь на многообразие имеющейся в их распоряжении информации (отчетности, сведений из регистрирующих, правоохранительных, налоговых органов и т.п.), определенным образом оценивают банки и в зависимости от этого вводят ограничители и лимиты на операции с ними, новая система искусственного интеллекта будет определять рейтинги физических лиц, на основании которых будут устанавливаться параметры кредитования конкретного человека. Использование искусственного интеллекта позволит избежать злоупотребления доверием со стороны безответственных физических лиц, поскольку по результатам его оценки будет даваться совершенно объективная и независимая оценка частных активов широкого круга отдельных физических лиц и на основании этого будет предоставляться каждому человеку право на частную эмиссию денег (путем установления кредитного лимита). Причем создаваться такая кредитно-рейтинговая система должна на базе Центрального банка [8]. Высокий уровень институционального доверия со стороны населения к ЦБ обспечит возможность эмиссии денег в соответствии с фидуциарным рейтингом, отражающим в свою очередь персонифицированное доверие к индивидам со стороны государственных институтов. Тем не менее, даже в этом случае Центральный Банк не способен эмитировать деньги, не подверженные манипулированию со стороны государства. В этом смысле мы не ратуем за введение традиционной системы частной эмиссии, при которой одновременно в обращении находятся несколько различных валют, конкурирующих между собой [10]. На наш взгляд механизм фидуциарного рейтинга позволит более грамотно подойти к оценке спроса на деньги 
со стороны хозяйствующих субъектов, на основе изучения их потребностей и возможностей, решив задачу определения денежной массы, необходимой для обращения. Внедрение цифровых технологий позволит решить данную задачу, не ограничивая при этом свободу действий индивидов, а, напротив, расширяя их возможности в реализации базовых потребностей.

\section{Библиографический список}

1. Бентам И. Введение в основания нравственности и законодательства / И. Бентам.- М.: РОССПЭН, 1998.c. $23-28$.

2. Коновалова М.Е, Кузьмина О.Ю. Трансформация финансовых институтов в условиях становления цифровой экономики // Вестник Самарского государственного экономического университета. 2018. № 6 (164). С. 13.

3. Коновалова М.Е., Михайлов А.М., Кузьмина О.Ю. Прогнозирование развития фондовых рынков в условиях становления цифровой экономики // Вестник Самарского государственного университета. 2018. № 11 (169). C. $13-19$.

4. Михайлов А.М. Влияние на процессы глобализации трансформации взаимодействия факторов производства в постиндустриальном обществе. // Экономические науки. 2008. № 43. С. 49-53.

5. Михайлов А.М., Андреев П.А. Формирование условий для развития цифровой экономики // Экономика и социология. 2017. № 36. С. 25-29.

6. Михайлов А. М. Роль человеческого капитала в реализации экономических и институциональных интересов собственников факторов производства // Вестник Саратовского госагроуниверситета им. Н.И. Вавилова. 2009. № 11. С. $72-76$.

7. Суриков К.Ю., Белобородов Д.В. Фидуциарный рейтинг физических лиц как основа частной эмиссии денег // Экономика и управление собственностью. 2012. № 2. С. 44.

8. Суриков К.Ю., Белобородов Д.В. Фидуциарный рейтинг физических лиц как средство измерения человеческого капитала // Экономические науки. 2011.№ 12. С. 18

9. Коновалова М.Е., Кузьмина О.Ю., Суриков К.Ю. Институциональное доверие и его роль в процессе развития денежно-кредитной сферы // Вестник Самарского государственного экономического университета.2016. № 11(145). С. 7.

10. Хайек Ф. Частные деньги. / Ф. фон. Хайек.- М.: ЭКСМО, 2010.- с. 123-128.

11. Хансевяров Р.И., Михайлов А.М., Сидюкова А.И. Факторы, влияющие на принятие инвестиционных решений на фондовом рынке // Экономические науки. 2018. № 162. С. 61-67. 